\title{
A Highly Water-Soluble Fluorescent and Colorimetric pH Probe
}

\author{
Rosita Diana ${ }^{1}$, Ugo Caruso ${ }^{2, *}$, , Angela Tuzi $^{2}$ and Barbara Panunzi ${ }^{1} \mathbb{C}$ \\ 1 Department of Agriculture, University of Napoli Federico II, 80055 Portici NA, Italy; \\ rosita.diana@unina.it (R.D.); barbara.panunzi@unina.it (B.P.) \\ 2 Department of Chemical Sciences, University of Napoli Federico II, 80126 Napoli, Italy; angela.tuzi@unina.it \\ * Correspondence: ugo.caruso@unina.it; Tel.: +39-081-674366
}

Received: 20 January 2020; Accepted: 1 February 2020; Published: 3 February 2020

\begin{abstract}
A new 5-(4-((2-(benzothiazole-2-carbonyl)hydrazono)methyl)-3-hydroxyphenoxy)$\mathrm{N}, \mathrm{N}, \mathrm{N}$-trimethylpentan-1-aminium bromide (BTABr) fluorescent and colorimetric $\mathrm{pH}$ probe was easily synthesized by the condensation reaction of benzothiazole-2-carbohydrazide with 5-(4-formyl-3-hydroxyphenoxy)-N,N,N-trimethylpentan-1-aminium bromide. The benzothiazole moiety provided the emissive part of the molecule and the charged trimethyl amino group guaranteed outstanding solubility in water, for an organic molecule. $\mathrm{pH}$ titration experiments indicated that the probe is useful for monitoring acidic and alkaline solutions, turning reversibly in color/fluorescence just at a neutral $\mathrm{pH}$ value. Naked-eye colorimetric response was observed both in solution and in the solid state. In addition, the probe showed high stability and selectivity and large Stokes shifts. Because of these features, $\mathrm{BTABr}$ can potentially work as an on-off real-time $\mathrm{pH}$ sensor for intracellular $\mathrm{pH}$ imaging. The crystal structure of BTABr examined by single-crystal analysis showed a planar geometry of the molecule and confirmed the presence of a molecular stacking between molecules joined in a complex tridimensional hydrogen bonding pattern.
\end{abstract}

Keywords: pH sensor; benzothiazole; water soluble; fluorescence

\section{Introduction}

The design of $\mathrm{pH}$-responsive molecules is a remarkable field of research, finding applications in environmental, biochemical, electrochemical, and analytical technologies [1,2]. As a key parameter for cell survival, its determination is crucial in living systems. Optical $\mathrm{pH}$ sensors are currently considered the cutting edge in the field of chemosensors due to the ease of use, low-cost process, high sensitivity and selectivity, and fast response [3-6].

Many optical $\mathrm{pH}$ sensors are both colorimetric and fluorometric $\mathrm{pH}$ probes. Typical fluorescence $\mathrm{pH}$ sensors are based on photoinduced electron transfer (PET), intramolecular charge transfer (ICT), and electron transfer (ET) effect. Organic molecules with a photon interaction site undergo electronic transfer effects turning in different tautomeric forms in a dependent manner from $\mathrm{pH}$. Among them, Schiff-base-containing molecules are excellent candidates to promote color/fluorescence response depending on protonation and deprotonation. On the other hand, fluorescence must be guaranteed by a suited emissive core. Heterocyclic molecules [7-21], as one of the most important classes of compounds, can play the role of fluorogenic moiety. At present, one of the major problems encountered in optimizing optical sensors is achieving the right balance between the presence of the fluorogenic unit (soluble in organic solvents) and the water solubility. Water-soluble $\mathrm{pH}$ sensors may provide a diagnostic tool $[22,23]$ by measuring intracellular $\mathrm{pH}$ gradient and evaluating the differences in $\mathrm{pH}$ between normal and altered cells. 
Recently, we designed and synthesized an amphiphilic picolinoyl-hydrazone-based sensor [24] with a charged side chain capable of guaranteeing water solubility. In that study, we checked the effect of the heterocycle on the spectroscopic response involving $\mathrm{pH}$ determination.

In the present work, we explored the potential of a benzothiazole moiety, one of the most widely known heterocycles, in the production of an optical $\mathrm{pH}$ sensor. A new highly water-soluble, 5-(4-((2(benzothiazole-2-carbonyl)hydrazono)methyl)-3-hydroxyphenoxy)-N,N,N-trimethylpentan-1-aminium bromide (BTABr) fluorescent and colorimetric probe was easily obtained by condensation reaction (see Scheme 1). In the keto-enolic tautomeric equilibrium, form $\mathbf{B}$ of the sensor undergoes two deprotonation steps, turning to forms $\mathbf{C}$ and finally $\mathbf{D}$, respectively, by increasing $\mathrm{pH}$ parameter. Variation of $\mathrm{pH}$ includes a variation in the electronic state of the molecule and consequently in the absorbance/emission spectra. A full characterization of the probe was performed by NMR spectroscopy, elemental analysis, mass spectrometry measurements, DSC/TGA methods, and absorption and emission titrations in the $\mathrm{pH}$ range of 2.0-11.0. Single-crystal X-ray analysis of the BTABr probe clarified the structural aspects.

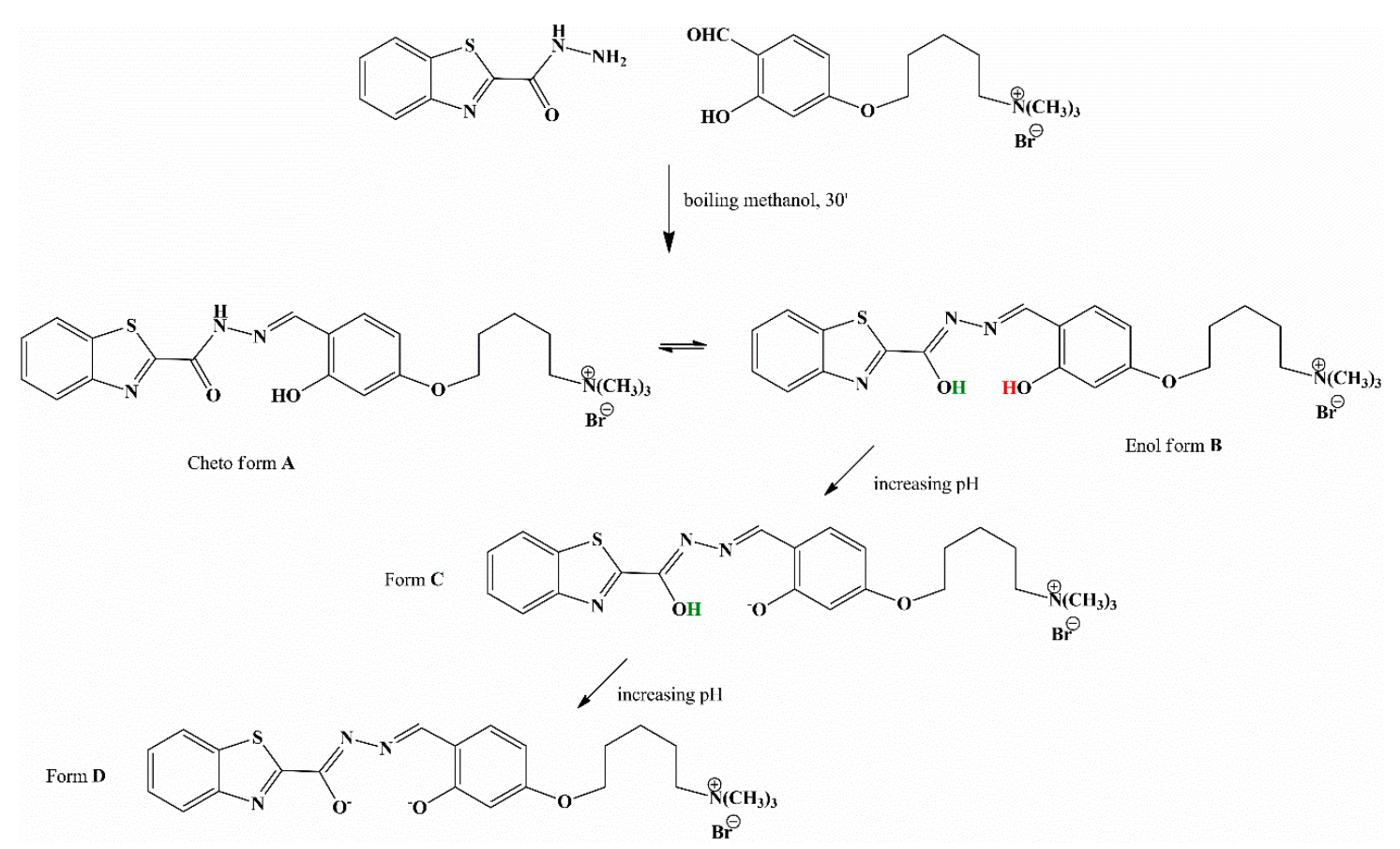

Scheme 1. Synthetic route to the target compound BTABr in the two tautomeric forms (A and $\mathbf{B})$ at $\mathrm{pH}$ acidic-neutral. In red, the more acid proton (lost in the $\mathbf{C}$ form) and, in green, the second acid proton (lost in the $\mathbf{D}$ form).

\section{Experimental Section}

All starting products were commercially available. 5-(4-Formyl-3-hydroxyphenoxy)-N,N,Ntrimethylpentan-1-aminium bromide [24] was obtained as described in the literature. Benzothiazole-2-carboxylic acid hydrazide [25] was obtained by common synthetic route placing ethyl benzothiazole-2-carboxylate under reflux in ethanol with an excess of hydrazine for $1 \mathrm{~h}$.

Optical microscopy was carried out with a Zeiss Axioscope polarizing microscope (Carl Zeiss, Oberkochen, Germany) equipped with a FP90 Mettler hot stage (Mettler-Toledo, LLC - Columbus, $\mathrm{OH}, \mathrm{USA})$. The decomposition temperature $\left(\mathrm{T}_{\mathrm{d}}\right)$, assumed as the temperature where is recorded the $5 \%$ weight loss, was determined by thermogravimetric analysis in air, using a PerkinElmer TGA 4000 (PerkinElmer, Inc., Waltham, MA, USA). Phase transition temperatures and enthalpies were measured using a PerkinElmer Pyris 1 DSC scanning calorimeter (PerkinElmer, Inc., Waltham, MA, USA) at a scanning rate of $10{ }^{\circ} \mathrm{C} / \mathrm{min}$, under nitrogen flow. ${ }^{1} \mathrm{H}$ NMR and ${ }^{13} \mathrm{C}$ NMR spectra were recorded with a 
Bruker $400 \mathrm{MHz}$ apparatus (Bruker Corporation, Billerica, MA, USA). Ultraviolet-visible (UV-Vis) and fluorescence spectra were recorded with JASCO spectrometers (JASCO Inc., Mary's Court, Easton, MD, USA).

\subsection{Synthesis of BTABr}

A $0.137 \mathrm{~g}$ (1.00 mmol) amount of benzothiazole-2-carboxylic acid hydrazide was added to $15 \mathrm{~mL}$ of a methanol solution containing $0.345 \mathrm{~g}(1.00 \mathrm{mmol})$ of 5-(4-formyl-3-hydroxyphenoxy)-N,N,Ntrimethylpentan-1-aminium bromide. The reaction mixture was refluxed for 30 min then was cooled to $0{ }^{\circ} \mathrm{C}$. Under this condition, a pale yellow crystalline solid precipitates. The solid was recovered by filtration and crystallized from methanol. Yield: $80 \%$. $\mathrm{Mp}=252{ }^{\circ} \mathrm{C}, \Delta \mathrm{H}=84.69 \mathrm{~J} / \mathrm{g}$. Decomposition temperature: $293^{\circ} \mathrm{C} .{ }^{1} \mathrm{H} \mathrm{NMR}\left(400 \mathrm{MHz}, \mathrm{DMSO}-\mathrm{d}_{6}, 25^{\circ} \mathrm{C}\right): \delta=12.82(\mathrm{~s}, 1 \mathrm{H}), 11.26(\mathrm{~s}, 1 \mathrm{H}), 8.73(\mathrm{~s}, 1 \mathrm{H})$, $8.24(\mathrm{~d}, 4.2 \mathrm{~Hz}, 1 \mathrm{H}), 8.17(\mathrm{~d}, 4.3 \mathrm{~Hz}, 1 \mathrm{H}), 7.65(\mathrm{t}, 5.4 \mathrm{~Hz}, 1 \mathrm{H}), 7.60(\mathrm{t}, 6.8 \mathrm{~Hz}, 1.7 \mathrm{~Hz}, 1 \mathrm{H}), 7.41(\mathrm{~d}, 7.0 \mathrm{~Hz}$, $1 \mathrm{H}), 6.49(\mathrm{~d}, 6.9 \mathrm{~Hz}, 1 \mathrm{H}), 6.48(\mathrm{~s}, 1 \mathrm{H}), 4.00(\mathrm{t}, 6.6 \mathrm{~Hz}, 2 \mathrm{H}), 3.28(\mathrm{~m}, 2 \mathrm{H}), 2.47(\mathrm{~s}, 9 \mathrm{H}), 1.74(\mathrm{~m}, 4 \mathrm{H})$, $1.40(\mathrm{~m}, 2 \mathrm{H}) \mathrm{ppm} .{ }^{13} \mathrm{C}$ NMR $\left(400 \mathrm{MHz}, \mathrm{DMSO}-\mathrm{d}_{6}, 25{ }^{\circ} \mathrm{C}\right): \delta=163.7,162.3,160.0,156.3,153.2,151.7$, 136.5, 131.8, 127.8, 127.6, 124.6, 123.5, 112.1, 107.6, 102.1, 67.8, 65.7, 52.7, 28.4, 22.8, 22.2.

HRMS(ESI): $\mathrm{m} / \mathrm{z}$ calculated for $\mathrm{C}_{23} \mathrm{H}_{29} \mathrm{~N}_{4} \mathrm{O}_{3} \mathrm{~S}^{+}: 441.566$; found $441.193[\mathrm{M}]^{+}$.

Elemental analysis calculated (\%) for $\mathrm{C}_{23} \mathrm{H}_{29} \mathrm{~N}_{4} \mathrm{O}_{3} \mathrm{SBr}$ : C, 52.96; H, 5.61; N, 10.74; found: C, 52.93; H, 5.67; N, 10.70 .

\subsection{X-ray Crystallography}

X-ray crystal structure analysis was carried out on single crystals of BTABr obtained from slow evaporation of acetone/water solution at room temperature. One selected crystal was mounted in flowing $\mathrm{N}_{2}$ at $173 \mathrm{~K}$ on a Bruker-Nonius KappaCCD diffractometer equipped with an Oxford Cryostream apparatus (graphite monochromated $\mathrm{MoK}_{\alpha}$ radiation, $\lambda=0.71073 \AA$, CCD rotation images, thick slices, $\varphi$ and $\omega$ scans to fill asymmetric unit). The structure was solved by direct methods (SIR97 program [26]) and anisotropically refined by the full matrix least-squares method on $F^{2}$ against all independent measured reflections using SHELXL-2018/3 [27] and WinGX software [28]. In BTABr crystallization, $\mathrm{H}_{2} \mathrm{O}$ is present. The $\mathrm{H}$ atoms bound to $\mathrm{N}$ (amide), to the hydroxy group, and to the $\mathrm{O}$ (water) were located in different Fourier maps and their coordinates were refined with $U_{\text {iso }}(\mathrm{H})$ equal to $1.2 U_{\mathrm{eq}}$ of the carrier atom. Some constraints were introduced in the last stage of refinement to regularize some $\mathrm{H}_{2} \mathrm{O}$ hydrogens (DFIX command of SHELXL). All the other hydrogen atoms were introduced in calculated positions and refined according to a riding model $(\mathrm{C}-\mathrm{H}$ distances equal to $0.95-0.99 \AA$ and $U_{\text {iso }}(\mathrm{H})$ equal to $1.2 U_{\text {eq }}$ of the carrier atom). Crystals resulted in being twinned (-1 $00,0-10,-101$ twinning law), no merging of reflections was made, and HKLF5 command was used. Crystal data and structure refinement details are reported in Table 2. Hydrogen bond geometry is reported in Table 3. The figures were generated using the ORTEP-3 [28] and Mercury CSD 4.0 [29] programs.

Crystal data were deposited at the Cambridge Crystallographic Data Centre with assigned number CCDC 1954197. These data can be obtained free of charge from www.ccdc.cam.ac.uk/data_request/cif.

Table 1. Crystal data and structure refinement details for BTABr.

\begin{tabular}{cc}
\hline CCDC Number & $\mathbf{1 9 5 4 1 9 7}$ \\
\hline Empirical formula & $\mathrm{C}_{23} \mathrm{H}_{35} \mathrm{Br} \mathrm{N}_{4} \mathrm{O}_{6} \mathrm{~S}$ \\
Formula weight & 575.52 \\
$\mathrm{~T}(\mathrm{~K})$ & $173(2)$ \\
$\lambda(\AA)$ & 0.71073 \\
Crystal system & Triclinic \\
Space group & $P 2_{1} / c$ \\
\hline
\end{tabular}


Table 2. Crystal data and structure refinement details for BTABr.

\begin{tabular}{cc}
\hline CCDC Number & $\mathbf{1 9 5 4 1 9 7}$ \\
\hline$a(\AA)$ & $8.205(4)$ \\
$b(\AA)$ & $12.931(4)$ \\
$c(\AA)$ & $13.086(7)$ \\
$a\left(^{\circ}\right)$ & $88.71(7)$ \\
$\beta\left(^{\circ}\right)$ & $74.22(6)$ \\
$\gamma\left(^{\circ}\right)$ & $81.81(4)$ \\
$\mathrm{V}\left(\AA^{3}\right)$ & $1322.3(11)$ \\
$\mathrm{Z}$ & 2 \\
$\mathrm{D}_{\text {calc }}\left(\mathrm{Mg} / \mathrm{m}^{3}\right)$ & 1.446 \\
$\mu\left(\mathrm{mm}^{-1}\right)$ & 1.678 \\
$\mathrm{~F}(000)$ & 600 \\
$\theta$ range $\left(^{\circ}\right)$ & 2.2527 .497 \\
Reflections collected/unique & $18815 / 18815$ \\
Data/restraints/parameters & $18815 / 10 / 340$ \\
Goodness-of-fit on $\mathrm{F}^{2}$ & 1.165 \\
Final $R, w R$ indices $[\mathrm{I}>2 s(\mathrm{I})]$ & $0.0623,0.1639$ \\
Final $R, w R$ indices (all data) & $0.0859,0.1895$ \\
Largest diff. peak / hole $\left(\mathrm{eA}{ }^{-3}\right)$ & $1.959 /-0.869$ \\
\hline
\end{tabular}

Table 3. Hydrogen bonding geometry for BTABr (e.s.d. values are in parentheses).

\begin{tabular}{|c|c|c|c|c|}
\hline $\mathrm{D}-\mathrm{H} \cdots \mathrm{A}$ & $\mathrm{d}(\mathrm{D}-\mathrm{H}) \AA$ & $\mathrm{d}(\mathrm{H} \cdots \mathrm{A}) \AA$ & $d(D \cdots A) \AA$ & $<(\mathrm{D}-\mathrm{H} \cdots \mathrm{A})^{\circ}$ \\
\hline $\mathrm{C}(9)-\mathrm{H}(9) \ldots \mathrm{O}(6)^{(i)}$ & 0.95 & 2.56 & $3.333(10)$ & 139.0 \\
\hline $\mathrm{C}(16)-\mathrm{H}(16 \mathrm{~B}) \ldots \mathrm{O}^{(i i)}$ & 0.99 & 2.61 & $3.570(10)$ & 163.3 \\
\hline $\mathrm{C}(21)-\mathrm{H}(21 \mathrm{~B}) \ldots \mathrm{O}(1)^{(i i i)}$ & 0.98 & 2.35 & $3.236(10)$ & 150.3 \\
\hline $\mathrm{C}(23)-\mathrm{H}(23 \mathrm{~B}) \ldots \mathrm{O}(1)$ & 0.98 & 2.37 & $3.235(11)$ & 147.4 \\
\hline $\mathrm{N}(2)-\mathrm{H}(2 \mathrm{~A}) \ldots \mathrm{O}(6)^{(i)}$ & 0.88 & 1.98 & $2.829(9)$ & 161.9 \\
\hline $\mathrm{O}(2)-\mathrm{H}(2 \mathrm{~B}) \ldots \mathrm{N}(3)$ & $0.73(9)$ & $1.98(9)$ & $2.578(8)$ & $139(10)$ \\
\hline $\mathrm{O}(4)-\mathrm{H}(4 \mathrm{~A}) \ldots \mathrm{Br}(1)$ & $0.832(18)$ & $2.59(3)$ & $3.399(6)$ & $163(8)$ \\
\hline $\mathrm{O}(4)-\mathrm{H}(4 \mathrm{~B}) \ldots \mathrm{O}(2)$ & $0.833(18)$ & $2.02(3)$ & $2.813(8)$ & 158(7) \\
\hline $\mathrm{O}(5)-\mathrm{H}(5 \mathrm{~A}) \ldots \mathrm{O}(4)$ & $0.842(18)$ & $1.97(2)$ & $2.814(8)$ & $175(7)$ \\
\hline $\mathrm{O}(6)-\mathrm{H}(6 \mathrm{~A}) \ldots \mathrm{O}(5)$ & $0.848(18)$ & $1.89(2)$ & $2.733(8)$ & $173(8)$ \\
\hline $\mathrm{O}(6)-\mathrm{H}(6 \mathrm{~B}) \ldots \mathrm{Br}(1)^{(i i)}$ & $0.841(18)$ & $2.514(19)$ & $3.352(6)$ & $174(7)$ \\
\hline
\end{tabular}

Symmetry code: $($ i $)=-\mathrm{x}+1,-\mathrm{y}+1,-\mathrm{z} ;(i i)=-\mathrm{x},-\mathrm{y}+1,-\mathrm{z}+1 ;$ (iii) $=\mathrm{x}-1, \mathrm{y}+1, \mathrm{z} ;(i \mathrm{v})=-\mathrm{x}+1,-\mathrm{y}+1,-\mathrm{z}+1$;

\subsection{UV-Vis and Fluorescence $p H$ Titrations and Naked-Eye Detection}

Stock solutions (1.00M) of Britton-Robinson buffer (at 2.0, 3.0, 4.0, 5.0, 6.0, 7.0, 8.0, 9.0, 10.0, and $11.0 \mathrm{pH}$ value) were prepared in bidistilled water ( $\mathrm{pH} 6.25)$ as described in the literature [30]. Aqueous solutions of BTABr (100 $\mu \mathrm{M}$ and $20 \mu \mathrm{M}$, respectively), from bidistilled water, were prepared for fluorescence and absorbance titrations. The probe titration was performed by adding $60 \mu \mathrm{L}$ of the buffer stock solutions to $2.5 \mathrm{~mL}$ of BTABr dissolved in the solvent. After mixing for a few seconds, the absorption or fluorescence spectra were recorded at room temperature.

For the naked-eye detection, solutions of $200 \mu \mathrm{M}$ of BTABr in $1.00 \mathrm{M}$ buffer of $\mathrm{pH}$ 2.0, 3.0, 4.0, 5.0, 6.0, 7.0, 8.0, 9.0, 10.0, and 11.0 were prepared. The laboratory paper soaked using a $0.01 \mathrm{M}$ water solution of the probe was Labor filter paper, $67 \mathrm{~g} / \mathrm{m}^{2}$, minimum porosity. The samples were immediately photographed. 


\section{Results and Discussion}

\subsection{Characterization and Sensing Ability of BTABr}

Compound BTABr was obtained as summarized in Scheme 1 by condensation reaction. ${ }^{1} \mathrm{H}-\mathrm{NMR}$ and ${ }^{13} \mathrm{C}-\mathrm{NMR}$ were used to identify the compounds and evaluate their degree of purity. Phase behavior was examined by optical observation as well as DSC and TGA analysis. The probe shows a large range of stability after melting (at $252{ }^{\circ} \mathrm{C}$ ) and no decomposition is detected until about $293{ }^{\circ} \mathrm{C}$ in air, making it a good candidate for its stability.

Remarkably, it was not necessary to employ mixed organic solvent-water solutions [31] because of the excellent water solubility of the probe $(0.12 \mathrm{M}$ in bidistilled water at $\mathrm{pH}=6.25$ for the protonated form). All photophysical measurements were performed in water solution or water-ethanol (8:2), the addition of ethanol slightly increasing emission intensity. The fluorescence quantum yield was measured in water for the deprotonated form $\mathbf{D}$ at $\mathrm{pH}=11.0$ by relative methods using quinine sulfate (QS) as standard (0.546 in $\mathrm{H}_{2} \mathrm{SO}_{4} 1 \mathrm{~N}$, excited at $365 \mathrm{~nm}$ ) according to [32-34]. The value of $6.20 \%$ is comparable to that reported for water-soluble $\mathrm{pH}$ probes $[35,36]$. In more concentrated solutions, the emission increases become perceptible to the naked eye (see Section 2.3).

In the UV-Vis experiments, the absorption maximum was recorded at about $351 \mathrm{~nm}$ for the chromophore in the protonated form (at pH from 2.0 to 6.0). In the $\mathrm{pH}$ range from 8.0 to 11.0, the peak undergoes a relevant red shift to about $425 \mathrm{~nm}$, consistent with the gradual deprotonation of the tautomeric form $\mathbf{B}$ to the deprotonated forms $\mathbf{C}$ and then $\mathbf{D}$ in increasingly basic media. At $\mathrm{pH}=7.0$, the absorbance pattern reveals two peaks at $344 \mathrm{~nm}$ and at $425 \mathrm{~nm}$. This behavior is evident in Figure 1 (on the left) where the titration in the $100 \mu \mathrm{M}$ water solution of BTABr is reported. The acidic solutions are pale yellow and the broad absorption band at about $425 \mathrm{~nm}$ is responsible for the bright yellow color of the basic solutions. The naked-eye response of the same solutions is quite evident (see Figure 2, solutions in natural light). The net color change from acidic to alkaline forms is observable also when the probe is adsorbed on laboratory paper (Figure 2, paper disc, upper half).
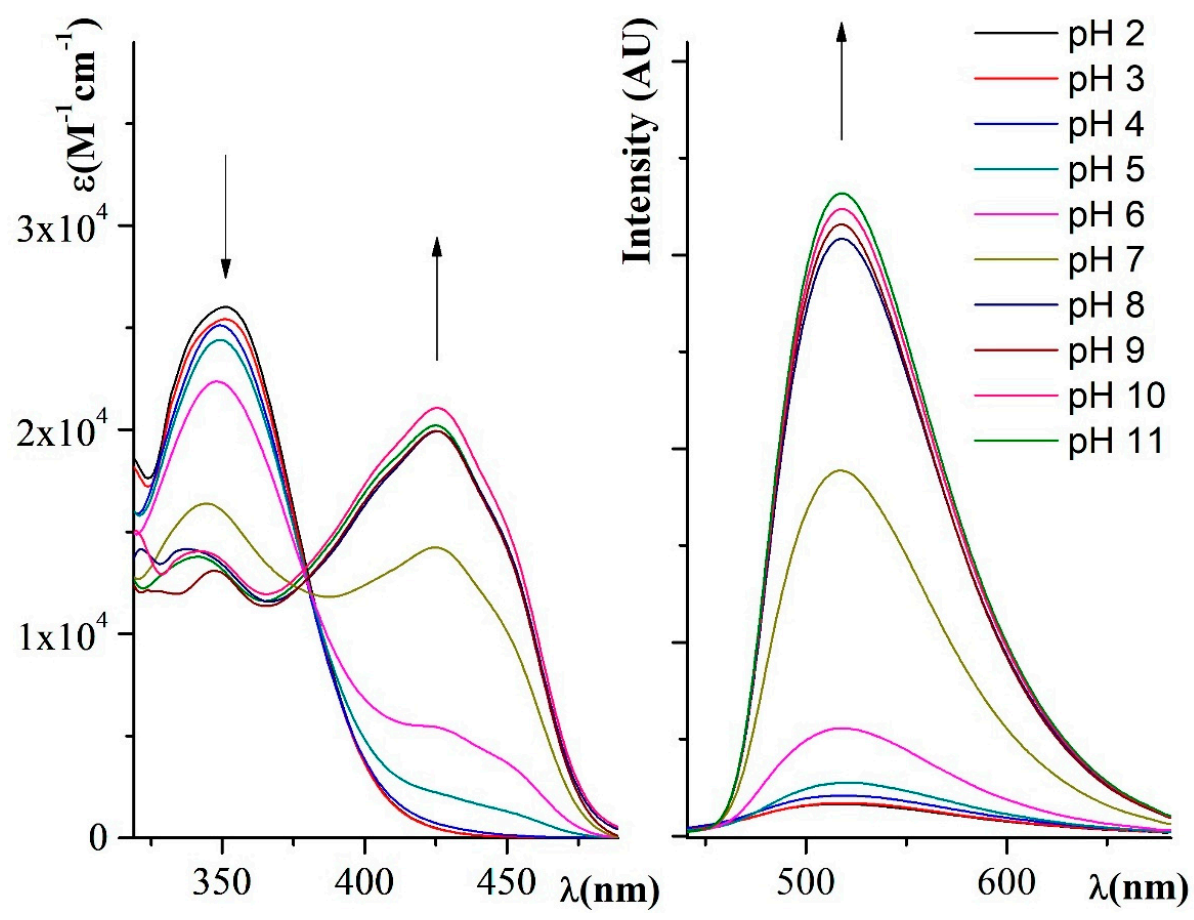

Figure 1. UV-Visible (UV-Vis) spectral titration of BTABr $100 \mu \mathrm{M}$ in water using Britton-Robinson buffers from $\mathrm{pH}=2.0$ to $\mathrm{pH}=11.0$ (on the left). Fluorescence spectral titration of BTABr $20 \mu \mathrm{M}$ in water using Britton-Robinson buffers from $\mathrm{pH}=2.0$ to $\mathrm{pH}=11.0$ (excitation wavelength of $350 \mathrm{~nm}$ ). 


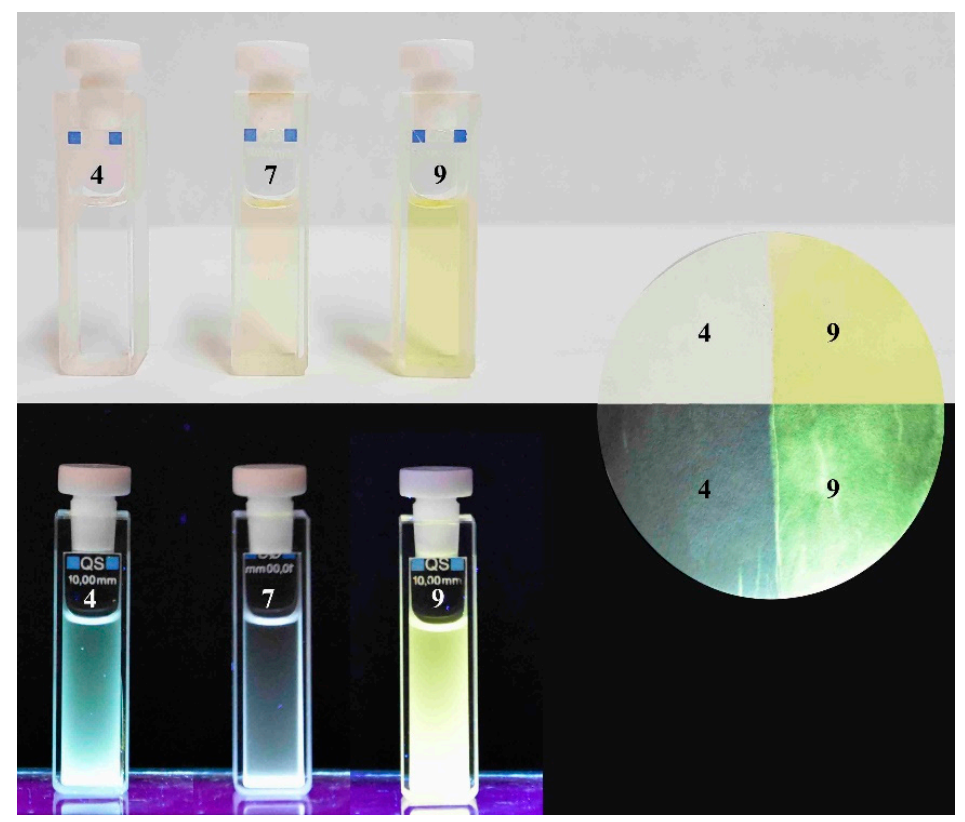

Figure 2. On the left: color of $100 \mu \mathrm{M}$ BTABr probe in buffer of $\mathrm{pH}=4.0, \mathrm{pH}=7.0$, and $\mathrm{pH}=9.0$ photographed under visible light (above) and UV lamp at $365 \mathrm{~nm}$ (below). On the right: color of laboratory paper soaked in the probe at $\mathrm{pH}=4.0$ (on the left) and $\mathrm{pH}=9.0$ (right) photographed at visible light (above) and under UV lamp at $365 \mathrm{~nm}$ (down).

The diagram of the fluorescence titration performed using the $20 \mu \mathrm{M}$ solution of BTABr in water is reported in Figure 1 on the right. The emission was recorded as a band peaked at $517 \mathrm{~nm}$ which increases and sharpens from the 2.0 to $11.0 \mathrm{pH}$ values. The acid solutions are much less intense in emission with respect to the basic ones, as can be observed with the naked eye in Figure 2 (solutions photographed in UV-Vis light). The same behavior is shown by the soaked-on paper sample (Figure 2, paper disc, lower half). Under the UV-Vis lamp, the deprotonated samples give a more intense yellow emission with respect to the quite colorless protonated form.

Finally, high Stokes shifts were evaluated in the basic range $(92 \mathrm{~nm})$, becoming even larger in the acidic solution $(166 \mathrm{~nm})$. Replicability and reversibility were positively checked by repeatedly turning on and off absorbance/fluorescence real-time response by $\mathrm{NaOH}$ or $\mathrm{HCl}$ addition in the fluorescence/absorbance experiments.

\subsection{Crystal Structure of BTABr}

A complete XRD analysis was performed on the single crystals of the BTABr probe obtained from slow evaporation of the acetone/water solution at room temperature. BTABr crystallizes in the triclinic $\mathrm{P}-1$ space group with one $\mathrm{BTA}^{+}$cation, one bromine anion, and three lattice water molecules contained in the independent unit. All bond lengths and angles are in the normal range. Crystal data and structural details are reported in Table 2. The hydrogen bonding geometry is reported in Table 3 . The ORTEP view of the molecular structure is reported in Figure 3.

The pattern of bond lengths in the compound agrees with the more stable keto form A of Scheme 1; in particular, the typical carbonyl double bond distance of 1.219(9) $\AA$ is found for the C8-O1 bond. The presence of the $\mathrm{N}$ (amide) hydrogen atom is proved by its localization in different Fourier maps. The existence of an intramolecular hydrogen bond between the $\mathrm{OH}$ donor and the $\mathrm{N}$ (imine) acceptor groups locks the phenol-azo group into a planar conformation (Table 3). In the side benzothiazole group, the $\mathrm{N}$ (thiazole) is cis-disposed to the $\mathrm{N}$ (amide) atom. A slight inclination of the benzotriazole group with respect to the phenol ring is observed, mainly due to the torsion around the C7-C 8 bond (N1-C7-C8-N2 $\left.=7.3(11)^{\circ}\right)$. The side oxoalkylamino group is in the all-trans conformation and in plane with the attached phenol group, except for the terminal $-\mathrm{CH}_{2}-\mathrm{N}\left(\mathrm{CH}_{3}\right)_{3}$ group that protrudes out 
of the mean plane of the molecule as a consequence of the torsion angle around the C18-C19 bond $\left(\mathrm{C} 17-\mathrm{C} 18-\mathrm{C} 19-\mathrm{C} 20=-68.3(9)^{\circ}\right)$. In this way a flat, elongated hooked shape of the molecular cation is achieved (Figure 3).
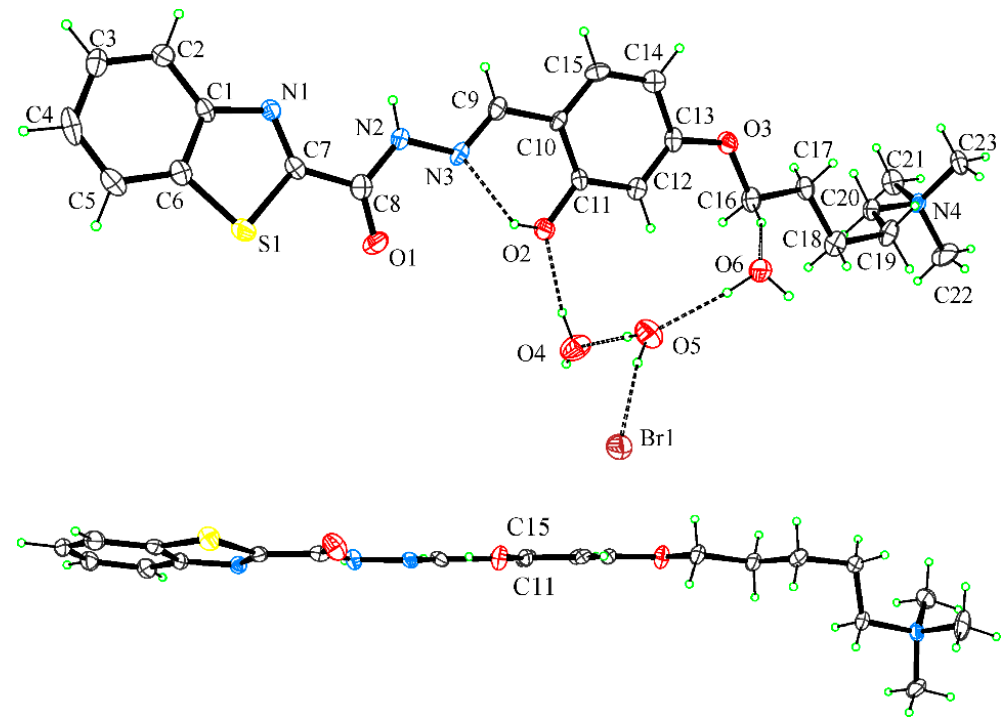

Figure 3. UP: Ortep view of BTABr normal to phenol ring with the $\mathrm{H}$ bonding pattern of $\mathrm{H}_{2} \mathrm{O}$ molecules drawn as dashed lines. DOWN: view of $\mathrm{BTA}^{+}$cation down the $\mathrm{C} 11-\mathrm{C} 15$ line. Thermal ellipsoids are drawn at $50 \%$ probability level.

The crystal packing is stabilized by intermolecular hydrogen bonds that involve the strong donor/acceptor groups of the molecule, the lattice water molecules, and the bromine anion in a complex tridimensional H-bonding pattern. In the molecule, the imine group acts as donor towards a water molecule and the hydroxy group acts as acceptor from another water molecule. The lattice water molecules are also involved in hydrogen bonds with the acceptor bromine anion to form an H-bonded ring across a crystallographic inversion center having an R4,6(12) graph set (Figure 4). In the crystal packing, the molecules are joined through $\mathrm{H}$-bonded water molecules in an antiparallel stacking at about $3.4 \AA$, with benzothiazole and alkyl groups of adjacent molecules facing each other and adjacent phenol rings slipped to each other.

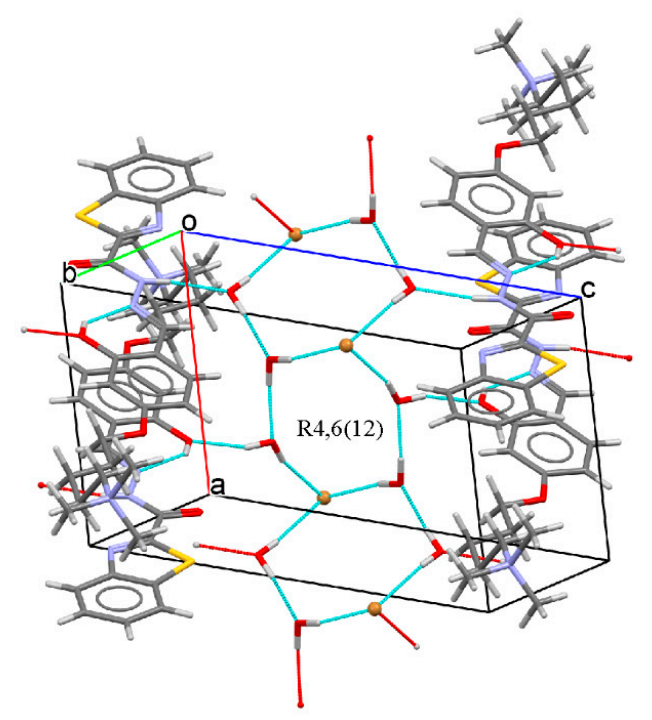

Figure 4. Partial packing showing the H-bonding pattern. Intra- and intermolecular hydrogen bonds are drawn as cyan dashed lines. 
The Hirshfeld surfaces and two-dimensional fingerprint plots using CrystalExplorer 17.5 [37] were utilized to analyze the close intermolecular contacts. The presence of hydrogen bonds was confirmed by the red spots on the Hirshfeld surface mapped over $\mathrm{d}_{\text {norm }}$ (Figure 5 , left) and by the bidimensional fingerprint plot (Figure 5, right).
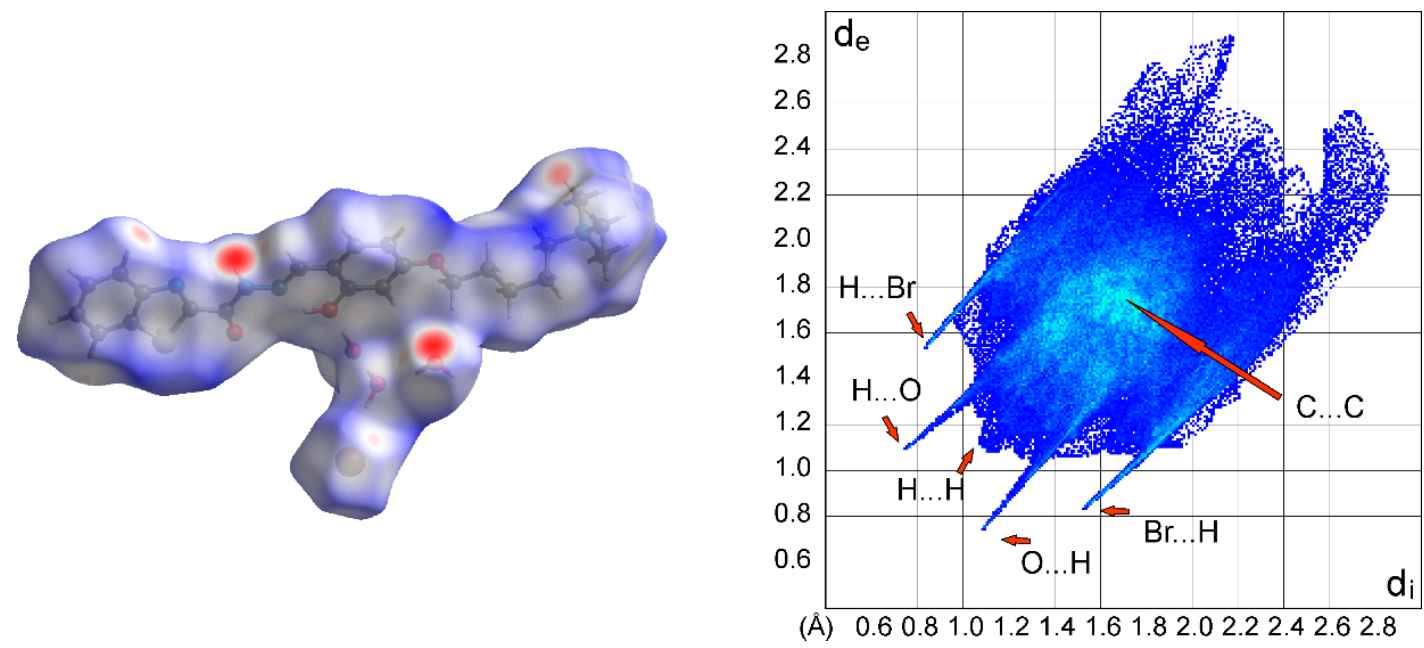

Figure 5. Left: Two-dimensional full fingerprint plot of BTABr. Significative contacts: H...H (46.2\%), O. . H H . . O (12.9\%), Br... H/H. . Br (10.8\%), and C . . C (2.7\%). Right: Hirshfeld surface mapped over $\mathrm{d}_{\text {norm. }}$

In the Hirshfeld fingerprint plot (Figure 5, right), the intermolecular $\mathrm{O} \cdots \mathrm{H} / \mathrm{H} \cdots \mathrm{O}(12.9 \%)$ and $\mathrm{Br} . . \mathrm{H} / \mathrm{H} \ldots \mathrm{Br}(10.8 \%)$ interactions are displayed as a pair of sharp spikes symmetrically disposed with respect to the diagonal. As expected, a large part of $\mathrm{H} \cdots \mathrm{H}(46.2 \%)$ interactions are found (diagonal blue strip that ends at about $\mathrm{d}_{\mathrm{i}}=\mathrm{d}_{\mathrm{e}}=1.1 \AA$ ). A small green area at about $\mathrm{d}_{\mathrm{i}}+\mathrm{d}_{\mathrm{e}}=3.4 \AA$ with a small amount of C. . C (2.7\%) interactions is diagnostic of few $\pi \cdots \pi$ interactions between molecules, due to their antiparallel stacking with prevalent contacts between alkyl and aromatic groups.

\section{Conclusions}

The $\mathrm{BTABr}$ probe shows a remarkable $\mathrm{pH}$-dependent behavior both in absorbance and in emission and a net on-off switch effect at neutral $\mathrm{pH}$. The effect is clearly perceivable even to the naked eye in solution and on the soaked-on paper sample. Common drawbacks of many $\mathrm{pH}$ probes, such as scarce stability, replicability and reversibility, slow response, and narrow Stokes shifts do not affect $\mathrm{BTABr}$. Moreover, the sensor is so soluble in water that it can be dissolved without any addition of organic solvents. Based on these characteristics, BTABr is a good candidate as on-off colorimetric and fluorescence real-time $\mathrm{pH}$ sensor, potentially employable for biological determinations.

Author Contributions: For research articles with several authors, a short paragraph specifying their individual contributions must be provided. The following statements should be used U.C., B.P., and R.D. conceptualized and designed the experiments; R.D., and A.T. performed the experiments; R.D. and B.P. analyzed the data; U.C. methodology, resources and wrote the paper. All authors have read and agreed to the published version of the manuscript.

Funding: This research was funded by by the Italian Ministry of Education, University and Research (MIUR) (Piano Lauree Scientifiche "Scienza dei Materiali" 2016-2018).

Conflicts of Interest: The authors declare no conflict of interest.

\section{References}

1. Das, D.K.; Dutta, K. pH dependent fluorescence switching in salicylideneaniline: 'off-on-off' operation controlled by surfactant micelles. J. Lumin. 2014, 145, 454-458. [CrossRef] 
2. Kumar, J.; Sarma, M.J.; Phukan, P.; Das, D.K. Surfactant Dependent pH Controlled “off-on”, "off-on-off” and "on-off" Fluorescent Switches Exhibited by N-Benzylidenenaphthalen-1-Amine. J. Fluoresc. 2015, 25, 1431-1435. [CrossRef] [PubMed]

3. Ni, Y.; Wu, J. Far-red and near infrared BODIPY dyes: Synthesis and applications for fluorescent $\mathrm{pH}$ probes and bio-imaging. Org. Biomol. Chem. 2014, 12, 3774-3791. [CrossRef] [PubMed]

4. Werner, T.; Huber, C.; Heinl, S.; Kollmannsberger, M.; Daub, J.; Wolfbeis, O.S. Novel optical pH-sensor based on a boradiaza-indacene derivative. Fresenius' J. Anal. Chem. 1997, 359, 150-154. [CrossRef]

5. Kollmannsberger, M.; Rurack, K.; Resch-Genger, U.; Daub, J. Ultrafast Charge Transfer in Amino-Substituted Boron Dipyrromethene Dyes and Its Inhibition by Cation Complexation: A New Design Concept for Highly Sensitive Fluorescent Probes. J. Phys. Chem. A 1998, 102, 10211-10220. [CrossRef]

6. Valeur, B. Molecular Fluorescence. Digit. Encycl. Appl. Phys. 2009, 477-531. [CrossRef]

7. Roviello, A.; Borbone, F.; Carella, A.; Diana, R.; Roviello, G.; Panunzi, B.; Ambrosio, A.; Maddalena, P. High quantum yield photoluminescence of new polyamides containing oligo-PPV amino derivatives and related oligomers. J. Polym. Sci. Part A Polym. Chem. 2009, 47, 2677-2689. [CrossRef]

8. Chalansonnet, V.; Lowe, J.; Orenga, S.; Perry, J.D.; Robinson, S.N.; Stanforth, S.P.; Sykes, H.E.; Truong, T.V. Fluorogenic 7-azidocoumarin and 3/4-azidophthalimide derivatives as indicators of reductase activity in microorganisms. Bioorganic Med. Chem. Lett. 2019, 29, 2354-2357. [CrossRef]

9. Stress, C.J.; Schmidt, P.J.; Gillingham, D.G. Comparison of boron-assisted oxime and hydrazone formations leads to the discovery of a fluorogenic variant. Org. Biomol. Chem. 2016, 14, 5529-5533. [CrossRef]

10. Piotto, S.; Concilio, S.; Sessa, L.; Diana, R.; Torrens, G.; Juan, C.; Caruso, U.; Iannelli, P. Synthesis and Antimicrobial Studies of New Antibacterial Azo-Compounds Active against Staphylococcus aureus and Listeria monocytogenes. Molecules 2017, 22. [CrossRef]

11. Zanotti, K.J.; Silva, G.L.; Creeger, Y.; Robertson, K.L.; Waggoner, A.S.; Berget, P.B.; Armitage, B.A. Blue fluorescent dye-protein complexes based on fluorogenic cyanine dyes and single chain antibody fragments. Org. Biomol. Chem. 2011, 9, 1012-1020. [CrossRef] [PubMed]

12. Panunzi, B.; Concilio, S.; Diana, R.; Shikler, R.; Nabha, S.; Piotto, S.; Sessa, L.; Tuzi, A.; Caruso, U. Photophysical Properties of Luminescent Zinc(II)-Pyridinyloxadiazole Complexes and their Glassy Self-Assembly Networks. Eur. J. Inorg. Chem. 2018, 2018, 2709-2716. [CrossRef]

13. Panunzi, B.; Borbone, F.; Capobianco, A.; Concilio, S.; Diana, R.; Peluso, A.; Piotto, S.; Tuzi, A.; Velardo, A.; Caruso, U. Synthesis, spectroscopic properties and DFT calculations of a novel multipolar azo dye and its zinc(II) complex. Inorg. Chem. Commun. 2017, 84, 103-108. [CrossRef]

14. Abbotto, A.; Beverina, L.; Bozio, R.; Bradamante, S.; Pagani, G.A.; Signorini, R. Heterocycle-based materials for frequency-upconverted lasing. Synth. Met. 2001, 121, 1755-1756. [CrossRef]

15. Rosenberg, L.S.; Simons, J.; Schulmans, S.G. Determination of pKa values of N-heterocyclic bases by fluorescence spectrophotometry. Talanta 1979, 26, 867-871. [CrossRef]

16. Borbone, F.; Caruso, U.; Concilio, S.; Nabha, S.; Piotto, S.; Shikler, R.; Tuzi, A.; Panunzi, B. From cadmium(II)-aroylhydrazone complexes to metallopolymers with enhanced photoluminescence. A structural and DFT study. Inorg. Chim. Acta 2017, 458, 129-137. [CrossRef]

17. Borbone, F.; Caruso, U.; Palma, S.D.; Fusco, S.; Nabha, S.; Panunzi, B.; Shikler, R. High solid state photoluminescence quantum yields and effective color tuning in polyvinylpyridine based zinc(II) metallopolymers. Macromol. Chem. Phys. 2015, 216, 1516-1522. [CrossRef]

18. Wu, Y.; Han, X.; Qu, Y.; Zhao, K.; Wang, C.; Huang, G.; Wu, H. Two Cu(I) complexes constructed by different N-heterocyclic benzoxazole ligands: Syntheses, structures and fluorescent properties. J. Mol. Struct. 2019, 1191, 95-100. [CrossRef]

19. Akchurin, I.O.; Yakhutina, A.I.; Bochkov, A.Y.; Solovjova, N.P.; Medvedev, M.G.; Traven, V.F. Novel push-pull fluorescent dyes-7-(diethylamino)furo- and thieno[3,2-c]coumarins derivatives: Structure, electronic spectra and TD-DFT study. J. Mol. Struct. 2018, 1160, 215-221. [CrossRef]

20. Jin, G.-X.; Ma, J.-P.; Dong, Y.-B. Metal-organic coordination polymers based on imidazolyl- and benzimidazolyl-containing 4,4'-bipy type ligands. J. Mol. Struct. 2013, 1052, 146-157. [CrossRef]

21. Diana, R.; Panunzi, B.; Tuzi, A.; Caruso, U. Two tridentate pyridinyl-hydrazone zinc(II) complexes as fluorophores for blue emitting layers. J. Mol. Struct. 2019, 1197, 672-680. [CrossRef]

22. Chen, J.W.; Chen, C.M.; Chang, C.C. A fluorescent $\mathrm{pH}$ probe for acidic organelles in living cells. Org. Biomol. Chem. 2017, 15, 7936-7943. [CrossRef] [PubMed] 
23. Panunzi, B.; Diana, R.; Concilio, S.; Sessa, L.; Tuzi, A.; Piotto, S.; Caruso, U. Fluorescence pH-dependent sensing of Zn(II) by a tripodal ligand. A comparative X-ray and DFT study. J. Lumin. 2019, 212, $200-206$. [CrossRef]

24. Diana, R.; Panunzi, B.; Tuzi, A.; Piotto, S.; Concilio, S.; Caruso, U. An Amphiphilic Pyridinoyl-hydrazone Probe for Colorimetric and Fluorescence pH Sensing. Molecules 2019, 24, 3833. [CrossRef] [PubMed]

25. Argeri, M.; Borbone, F.; Caruso, U.; Causà, M.; Fusco, S.; Panunzi, B.; Roviello, A.; Shikler, R.; Tuzi, A. Color tuning and noteworthy photoluminescence quantum yields in crystalline mono-/dinuclear ZnII complexes. Eur. J. Inorg. Chem. 2014, 2014, 5916-5924. [CrossRef]

26. Altomare, A.; Burla, M.C.; Camalli, M.; Cascarano, G.L.; Giacovazzo, C.; Guagliardi, A.; Moliterni, A.G.G.; Polidori, G.; Spagna, R. SIR97: A new tool for crystal structure determination and refinement. J. Appl. Crystallogr. 1999, 32, 115-119. [CrossRef]

27. Sheldrick, G.M. Crystal structure refinement with SHELXL. Acta Crystallogr. Sect. C Struct. Chem. 2015, 71, 3-8. [CrossRef]

28. Farrugia, L.J. WinGXandORTEP for Windows: An update. J. Appl. Crystallogr. 2012, 45, 849-854. [CrossRef]

29. Macrae, C.F.; Bruno, I.J.; Chisholm, J.A.; Edgington, P.R.; McCabe, P.; Pidcock, E.; Rodriguez-Monge, L.; Taylor, R.; van de Streek, J.; Wood, P.A. Mercury CSD 2.0-New features for the visualization and investigation of crystal structures. J. Appl. Crystallogr. 2008, 41, 466-470. [CrossRef]

30. Britton, H.T.S.; Robinson, R.A. CXCVIII.-Universal buffer solutions and the dissociation constant of veronal. J. Chem. Soc. 1931, 0, 1456-1462. [CrossRef]

31. Diana, R.; Caruso, U.; Concilio, S.; Piotto, S.; Tuzi, A.; Panunzi, B. A real-time tripodal colorimetric/fluorescence sensor for multiple target metal ions. Dyes and Pigment. 2018, 155, 249-257. [CrossRef]

32. Melhuish, W.H. Quantum Efficiencies of Fluorescence of Organic Substances: Effect of Solvent and Concentration of the Fluorescent Solute1. J. Phys. Chem. 1961, 65, 229-235. [CrossRef]

33. Williams, A.T.R.; Winfield, S.A.; Miller, J.N. Relative fluorescence quantum yields using a computer-controlled luminescence spectrometer. Analyst 1983, 108. [CrossRef]

34. Panunzi, B.; Diana, R.; Concilio, S.; Sessa, L.; Shikler, R.; Nabha, S.; Tuzi, A.; Caruso, U.; Piotto, S. Solid-state highly efficient $\mathrm{dr}$ mono and poly-dicyano-phenylenevinylene fluorophores. Molecules 2018, $23,1505$. [CrossRef]

35. Ma, P.; Liang, F.; Wang, D.; Yang, Q.; Yang, Z.; Gao, D.; Yu, Y.; Song, D.; Wang, X. A novel fluorescence and surface-enhanced Raman scattering dual-signal probe for $\mathrm{pH}$ sensing based on Rhodamine derivative. Dye. Pigment. 2015, 122, 224-230. [CrossRef]

36. Shih, K.-Y.; Hsiao, T.-S.; Deng, S.-L.; Hong, J.-L. Water-Soluble Poly( $\gamma$-propargyl-l-glutamate) Containing Pendant Sulfonate Ions and Terminal Fluorophore: Aggregation-Enhanced Emission and Secondary Structure. Macromolecules 2014, 47, 4037-4047. [CrossRef]

37. Turner, M.J.; Thomas, S.P.; Shi, M.W.; Jayatilaka, D.; Spackman, M.A. Energy frameworks: Insights into interaction anisotropy and the mechanical properties of molecular crystals. Chem. Commun. (Camb.) 2015, 51, 3735-3738. [CrossRef]

(C) 2020 by the authors. Licensee MDPI, Basel, Switzerland. This article is an open access article distributed under the terms and conditions of the Creative Commons Attribution (CC BY) license (http://creativecommons.org/licenses/by/4.0/). 